\title{
SPECIES STRUCTURE OF PLANTS IN THE BÁB FOREST AFTER LOGGING
}

\author{
IVANA PILKOVÁ
}

Department of Ecology and Environmental, Faculty of Natural Sciences, Constantine the Philosopher University in Nitra, Tr. A. Hlinku 1, Nitra, Slovak Republic; e-mail: ivana.pilkova@gmail.com

\begin{abstract}
Pilková I.: Species structure of plants in the Báb forest after logging. Ekológia (Bratislava), Vol. 34, No. 4, p. 293-308, 2015.

In the submitted paper, we have summarised the results of a research that was realised in the locality of the Báb forest (village Velký Báb, Nitra loess upland). In the area of Báb forest, we were able to document 134 higher plants on 32 permanent research plots (PRP) during 2013. One hundred and twenty-three taxa were documented in the PRP areas situated on clearcuts, whil only 75 were found in the PRP areas located in forest covers. On PRP of clearcuts, there was the highest cover of herb layer; on the other hand, in the forest cover, there was a higher cover of shrub and tree layer. The highest differences in life-forms between two groups of PRP (clearcuts/forest) were detected by hemicryptophytes and terophytes. On all the 32 areas, the biggest number of species belonged to the indigenous species and apophytes. The biggest differences between forests and clearcuts are shown in a representation of C-strategies. The species composition of the Báb forest has changed mainly due to creation of clearcut areas in November 2006. The logging created suitable conditions for the penetration of heliophilious non-indigenous species from the surrounding (mainly anthropogenic) habitats. That is why there are largely synanthropic and non-indigenous taxa represented on permanent clearcut areas, which are spreading further to the forest cover as well as distant areas of the Báb forest.
\end{abstract}

Key words: Báb forest, forest covers, clearcuts, indigenous species, non-indigenous taxa.

\section{Introduction}

The study presents results of the research realised in the Báb forest in 2013. This forest is remnant of original native forest complexes. In the past, it was marked by anthropogenic impacts, especially short rotation management. Its surroundings were mainly turned into wide-area fields and vineyards (Kubíček, Brechtl, 1970). The Báb forest represents a climax stage of forest succession on loess (Eliáš, 2010a). Fragments of forests in a deforested country being intensively exploited by agriculturers, are exposed to impacts of human activities. These fragments are more or less indigenous vegetation surrounded by disrupted, intensively farmed areas and biotopes with the predominance of synanthropic species (Eliáš, 2010a).

This fact also concerns the Báb forest. In November 2006, a one-time line and shelterwood logging was realised and therefore, a new type of post after tree removal was created in the area - a clearcut (Eliáš, 2010b). The target was to evaluate the biodiversity of plant species 
of two permanent area groups - PRP of the clearcut areas and of the forest cover on the basis of comparison of their species compositions, cover, life-forms and life strategies.

\section{Material and methods}

Administratively, the Báb forest area belongs to cadastre of village Velký Báb, district Nitra and to the Nitra region. Two reserve areas can be found here - the National Nature Reserve Báb forest and the Protected Area Báb Park.

In the area of Báb forest, 32 PRP were measured and permanently identified (Fig. 1). The overall measured and identified area was the size of $20 \times 20 \mathrm{~m}$. In the majority of cases, PRP were located in linear transects divided into groups of three. It is possible to divide the particular permanent research areas into three groups:

The first group is formed by PRP on clearcuts, which originated by a clearcut method of timber harvesting in November 2006. Each out of four clearcuts is formed by three PRP located in a linear transect. An overall number is 12 PRP. The next group consists of 11 areas, which are located forest covers that did not undergo harvesting. The last group of 9 areas is formed by indigenous forest communities called NNR Báb forest.

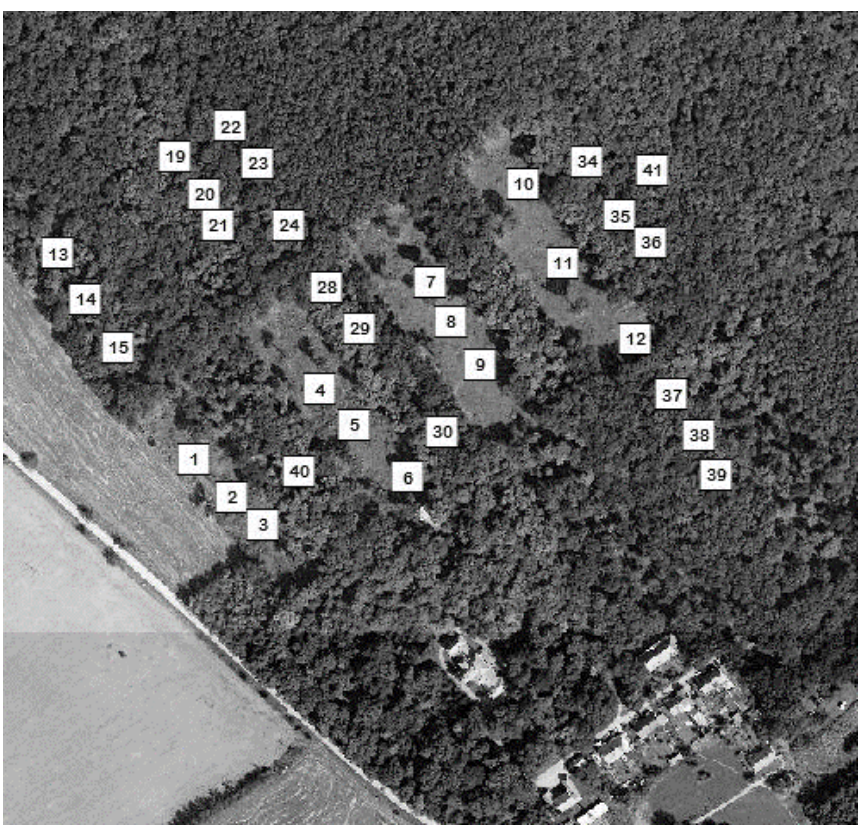

Fig. 1. The area of interest of Báb forest with marked permanent plots.

(Source: ILE SAS, branch Nitra).

The research of Báb Forest was made using phytocenological records, produced with standard phytocenological methods (Moravec, 1994), by using 9-membered ordinal scale (Westhof, van der Maarer, 1978):

$1-1$ or 2 individuals, 6 - abundance $12.5-25 \%$,

2 - more individuals, abundance less than $1 \%$, 7 - abundance $25-50 \%$,

3 - abundance $1-5 \%$ small number of individuals, 8 - abundance $50-75 \%$,

4 - abundance $1-5 \%$, many individuals, 9 - abundance more than $75 \%$.

5 - abundance 5-12.5\%,

Phytosociological records were inserted into the database Turbowin (Hennekens, Schaminee, 2001). Afterwards, the frequency of their occurrence (\%) and range of plant species abundances of two PRP groups was counted 
in the program JUICE (Tichý, 2002). I evaluated the structure of vegetation of permanent plots from different aspects:

1. the life-forms according to Dostál (1991, 1992),

2. the life strategies according to Frank, Klotz (1988),

3. the indigenous species according to Halada (1996),

4. the nonindigenous species according to Medvecká et al. (2012).

The program CANOCO was used for phytocenological data ordination (Lep̌̌, Šmilauer, 2000). The first entry which needed to be verified was an entry about the length of a gradient. The verification was done through a detrended analysis dentrendent correspondent analysis. In the case of all the analyses, their results showed only the presence of a short gradient. That was the reason why in the cases of further research, only a linear analysis, more specifically principal component analysis indirect linear analysis and regression-discontinuity Analysis direct analysis, was used. An indirect analysis PCA was used for an assessment of the differences in phytocenological records, hence in species composition of PRP on clearcut and forest covers as well.

A direct analysis RDA served for an analysis of life-forms, life strategies and synanthropisation. In the direct analysis, the given variables were inserted by a method of gradual selection and Monte Carlo permutation test with no restrictions used for the testing of statistical significance of the given variables ( 499 permutations). There were no covariants used in the analyses. Naming taxon identified was consistently treated according to the List of lower and higher plants in Slovakia (Marhold, Hindák, 1998).

\section{Results}

In the area of Báb forest, I was able to document 134 higher plants on 32 PRP during 2013. Out of the overal number of 134 higher plants, there were found 31 plants and 98 herbs. There were documented five species in the form of aggregates and five species in the form of genus. One hundred and twenty-three taxa were documented in PRP areas situated on clearcuts, while only 75 were found in PRP areas located in forest covers (Table 1).

Acer campestre, Carpinus betulus, Galeobdolon luteum, Galium odoratum, Geum urbanum, Glechoma hirsuta, Hedera helix, Lamium maculatum, Melica uniflora, Mercurialis perennis, Polygonatum latifolium, P. multiflorum, Pulmonaria officinalis, Viola mirabilis are the most widespread species (the frequency of which is from 80 until 100\%) belonging to a herb layer on PRP on clearcuts and in a forest cover. It is possible to say that the most widespread (frequency 50-79\%) species of both habitats are: Acer campestre in shrub layer, Alliaria petiolata, Anemone ranunculoides, Cornus mas, Euonymus europaeus, E. verrucosus, Ficaria bulbifera, Galium aparine, Ligustrum vulgare, Quercus cerris in herb layer.

The most widespread taxa (frequency 70-100\%), located only on PRP on clearcuts were: Carpinus betulus in shrub layer, Ailanthus altissima, Arctium lappa, A. tomentosum, Astragalus glycyphyllos, Calamagrostis epigejos, Cirsium arvense, C. vulgare, Erigeron annuus ssp. annuus, Euphorbia cyparissias, Galium aparine, Hypericum hirsutum, Inula conyzae, Quercus robur, Rosa canina agg., Stellaria media, Urtica dioica in herb layer. And the species with a frequency from 70 to $100 \%$ located in forest covers are Acer campestre, Carpinus betulus, Quercus cerris in trees layer, Cornus mas in shrub layer a Ligustrum vulgare in herb layer.

The records of PRP on clearcuts (red cross) and in forest covers (violet square) are substantially different from each other and PRP No. 4 is located between those PRP (Fig. 2). The given PRP does not show any interventions from timber harvesting (look below).

Common PRP species on clearcuts and in forest covers include 54 taxa. Those are mainly plants belonging to oak-hornbeam forests: Acer campestre, A. platanoides, Carpinus betulus, 
Table 1. Frequency of occurrence (\%) and range of plant species abundances of permanent research plots.

\begin{tabular}{|c|c|c|c|c|c|}
\hline Taxons & Species FC & Species C & Taxons & Species FC & Species C \\
\hline \multicolumn{3}{|c|}{ Tree layer - E3 (from $3 \mathrm{~m}$ height) } & \multicolumn{3}{|l|}{ Herb layer - E1 (to $1 \mathrm{~m}$ height) } \\
\hline Carpinus betulus & $95^{1-8}$ & $17^{1-8}$ & Galium odoratum & $100^{2-8}$ & $100^{1-8}$ \\
\hline Acer campestre & $75^{1-8}$ & $25^{1-4}$ & Mercurialis perennis & $100^{2-8}$ & $100^{1-8}$ \\
\hline Quercus cerris & $75^{1-8}$ & $17^{2-8}$ & Hedera helix & $100^{2-8}$ & $100^{1-8}$ \\
\hline Hedera helix & $50^{1-4}$ & - & Glechoma hirsuta & $100^{1-8}$ & $100^{1-8}$ \\
\hline Quercus petraea agg. & $40^{1-8}$ & $17^{2-8}$ & Viola mirabilis & $100^{1-4}$ & $98^{1-8}$ \\
\hline Quercus robur & $40^{1-8}$ & $8^{1-2}$ & Lamium maculatum & $100^{1-8}$ & $95^{1-4}$ \\
\hline Cornus mas & $20^{2-8}$ & - & Geum urbanum & $100^{1-8}$ & $92^{1-4}$ \\
\hline Sorbus torminalis & $20^{1-8}$ & - & Polygonatum multiflorum & $100^{1-8}$ & $90^{1-8}$ \\
\hline Robinia pseudoacacia & $5^{4}$ & $42^{1-4}$ & Alliaria petiolata & $100^{1-8}$ & $78^{1-8}$ \\
\hline Ulmus minor & $5^{4-8}$ & $8^{4-8}$ & Galium aparine & $100^{1-8}$ & $58^{1-8}$ \\
\hline Quercus virgiliana & $5^{4-8}$ & - & Quercus robur & $100^{1-8}$ & $20^{1-4}$ \\
\hline Ailanthus altissima & - & $17^{2-4}$ & Cirsium arvense & $100^{1-8}$ & - \\
\hline Acer platanoides & - & $8^{1-2}$ & Euphorbia cyparissias & $100^{1-8}$ & - \\
\hline \multicolumn{3}{|c|}{ Shrub layer - E2 (to $3 \mathrm{~m}$ height) } & Hypericum hirsutum & $100^{1-8}$ & - \\
\hline Acer campestre & $901-8$ & $581-8$ & Polygonatum latifolium & $96^{1-8}$ & $95^{1-8}$ \\
\hline Cornus mas & $851-8$ & $172-4$ & Acer campestre & $92^{1-8}$ & $100^{1-8}$ \\
\hline Carpinus betulus & $302-8$ & $1001-8$ & Melica uniflora & $92^{1-8}$ & $95^{1-8}$ \\
\hline Ulmus minor & $251-8$ & 82 & Galeobdolon luteum & $92^{1-8}$ & $88^{1-8}$ \\
\hline Crataegus laevigata & $251-8$ & - & Pulmonaria officinalis & $92^{1-8}$ & $88^{1-4}$ \\
\hline Sorbus torminalis & $251-4$ & - & Carpinus betulus & $92^{1-8}$ & $80^{1-8}$ \\
\hline Ligustrum vulgare & $202-4$ & $81-2$ & Cirsium vulgare & $92^{1-8}$ & - \\
\hline Crataegus monogyna & $201-4$ & - & Ailanthus altissima & $88^{1-8}$ & - \\
\hline Swida sanguinea & $151-2$ & - & Erigeron annuus ssp. annuus & $88^{1-4}$ & - \\
\hline Euonymus europaeus & $101-8$ & 88 & Calamagrostis epigejos & $83^{1-8}$ & $5^{2}$ \\
\hline Euonymus verrucosus & $101-3$ & - & Arctium lappa & $83^{1-8}$ & - \\
\hline Viburnum lantana & 51 & 88 & Urtica dioica & $75^{1-8}$ & $8^{1-2}$ \\
\hline Fraxinus excelsior & 58 & - & Astragalus glycyphyllos & $75^{1-8}$ & - \\
\hline Lonicera caprifolium & 52 & - & Stellaria media & $75^{1-8}$ & - \\
\hline Mahonia aquifolium & 52 & - & Rosa canina agg. & $75^{1-3}$ & - \\
\hline Quercus cerris & - & $501-4$ & Arctium tomentosum & $75^{1-2}$ & - \\
\hline Robinia pseudoacacia & - & $331-4$ & Inula conyzae & $71^{1-8}$ & - \\
\hline Quercus petraea agg. & - & $252-8$ & Ligustrum vulgare & $67^{2-8}$ & $75^{1-8}$ \\
\hline Quercus robur & - & $251-8$ & Euonymus europaeus & $67^{1-4}$ & $52^{1-3}$ \\
\hline Lonicera xylosteum & - & $212-8$ & Carduus acanthoides & $67^{1-8}$ & - \\
\hline Sambucus nigra & - & $211-4$ & Ajuga reptans & $62^{1-8}$ & $8^{1}$ \\
\hline Ailanthus altissima & - & 84 & Euonymus verrucosus & $58^{1-4}$ & $75^{1-4}$ \\
\hline Acer platanoides & - & 81 & Impatiens parviflora & $58^{1-8}$ & $48^{1-8}$ \\
\hline \multicolumn{6}{|c|}{ Herb layer - E1 (to $1 \mathrm{~m}$ height) } \\
\hline Geranium robertianum & $581-8$ & $15^{1-4}$ & Veronica chamaedrys & $17^{1-2}$ & - \\
\hline Sambucus nigra & $581-3$ & $15^{1-2}$ & Crataegus monogyna & $12^{1-2}$ & $62^{1-8}$ \\
\hline Rubus fruticosus agg. & $581-4$ & $2^{2}$ & Veronica officinalis & $12^{1}$ & $8^{1-4}$ \\
\hline Ficaria bulbifera & $541-8$ & $85^{1-8}$ & Viola riviniana & $12^{1-2}$ & $5^{1-2}$ \\
\hline Brachypodium sylvaticum & $541-8$ & $10^{1-2}$ & Carex muricata agg. & $12^{2}$ & - \\
\hline Securigera varia & $541-4$ & $10^{1}$ & Cirsium canum & $12^{2}$ & - \\
\hline
\end{tabular}


Table 1. Frequency of occurrence (\%) and range of plant species abundances of permanent research plots - continued.

\begin{tabular}{|c|c|c|c|c|c|}
\hline Taxons & Species FC & Species C & Taxons & Species FC & Species C \\
\hline Ajuga genevensis & $54^{1-4}$ & - & Solanum dulcamara & $12^{1-2}$ & - \\
\hline Quercus cerris & $50^{1-4}$ & $58^{1-4}$ & Verbascum austriacum & $12^{1-2}$ & - \\
\hline Anemone ranunculoides & $50^{1-8}$ & $50^{1-8}$ & Corydalis cava & $8^{1-2}$ & $22^{1-4}$ \\
\hline Cornus mas & $50^{1-3}$ & $55^{1-4}$ & Ulmus minor & $8^{3}$ & $15^{1-2}$ \\
\hline Viola odorata & $50^{1-8}$ & $45^{1-4}$ & Vinca minor & $8^{2-4}$ & $10^{2-8}$ \\
\hline Viola reichenbachiana & $50^{1-2}$ & $45^{1-2}$ & Carex pilosa & $8^{1}$ & $10^{1-4}$ \\
\hline Viola hirta & $50^{1-4}$ & $42^{1-4}$ & Carex sylvatica & $8^{2}$ & $5^{2-4}$ \\
\hline Poa nemoralis & $50^{1-4}$ & $5^{1}$ & Fallopia dumetorum & $8^{2-4}$ & $2^{4}$ \\
\hline Aster lanceolatus & $50^{1-4}$ & - & Lithospermum purpurocaeruleum & $8^{4-8}$ & - \\
\hline Aster novi-belgii agg. & $50^{1-2}$ & - & Linaria vulgaris & $8^{2-4}$ & - \\
\hline Carex sp. & $50^{1-2}$ & - & Vicia tetrasperma & $8^{2-4}$ & - \\
\hline Gagea lutea & $46^{1-8}$ & $50^{1-8}$ & Torilis japonica & $8^{1-4}$ & - \\
\hline Fragaria moschata & $46^{2-8}$ & - & Achillea millefolium & $8^{2}$ & - \\
\hline Serratula tinctoria & $46^{1-4}$ & - & Campanula rapunculoides & $8^{2}$ & - \\
\hline Glechoma hederacea & $42^{1-4}$ & $32^{1-4}$ & Lamium purpureum & $8^{2}$ & - \\
\hline Bromus benekenii & $42^{1-4}$ & $20^{1-2}$ & Lavatera thuringiaca & $8^{2}$ & - \\
\hline Swida sanguinea & $42^{1-8}$ & $5^{4-8}$ & Sonchus arvensis & $8^{2}$ & - \\
\hline Clematis vitalba & $42^{1-4}$ & - & Artemisia vulgaris & $8^{1-2}$ & - \\
\hline Corydalis solida & $38^{1-8}$ & $45^{2-8}$ & Erechtites hieraciifolius & $8^{1-2}$ & - \\
\hline Dentaria bulbifera & $38^{1-4}$ & $42^{1-8}$ & Lathyrus niger & $8^{1-2}$ & - \\
\hline Isopyrum thalictroides & $38^{1-4}$ & $35^{1-4}$ & Carex ovalis & $8^{1}$ & - \\
\hline Quercus petraea agg. & $33^{2-8}$ & $12^{1-4}$ & Oryzopsis virescens & $8^{1}$ & - \\
\hline Dactylis glomerata & $33^{1-4}$ & $8^{1-2}$ & Silene latifolia ssp. alba & $8^{1}$ & - \\
\hline Milium effusum & $33^{1-4}$ & $5^{1}$ & Verbascum sp. & $8^{1}$ & - \\
\hline Robinia pseudoacacia & $33^{1-4}$ & $5^{1}$ & Convallaria majalis & $4^{2}$ & $20^{1-4}$ \\
\hline Sambucus ebulus & $33^{1-8}$ & - & Chaerophyllum temulum & $4^{4}$ & - \\
\hline Viburnum lantana & $25^{2-4}$ & $50^{2-8}$ & Amaranthus retroflexus & $4^{2}$ & - \\
\hline Acer platanoides & $25^{1-2}$ & $28^{1-2}$ & Capsella bursa-pastoris & $4^{2}$ & - \\
\hline Roegneria canina & $25^{1-2}$ & $10^{1-2}$ & Echinochloa crus-galli & $4^{2}$ & - \\
\hline Ballota nigra & $25^{1-2}$ & - & Chenopodium hybridum & $4^{2}$ & - \\
\hline Crataegus laevigata & $21^{1-4}$ & $30^{1-8}$ & Persicaria lapathifolia & $4^{2}$ & - \\
\hline Vicia angustifolia & $21^{1-4}$ & - & Arctium sp. & $4^{1}$ & - \\
\hline Hypericum perforatum & $21^{1-2}$ & - & Holosteum umbellatum & $4^{1}$ & - \\
\hline Melica nutans & $21^{1-2}$ & - & Cerasus avium & - & $10^{1}$ \\
\hline Prunus spinosa & $17^{1-2}$ & $15^{1-2}$ & Lathyrus vernus & - & $10^{1}$ \\
\hline Mahonia aquifolium & $17^{3}$ & $5^{3}$ & Anthriscus cerefolium & - & $8^{1-2}$ \\
\hline Tussilago farfara & $17^{1-4}$ & - & Quercus virgiliana & - & $5^{1-2}$ \\
\hline Clinopodium vulgare & $17^{1-2}$ & - & Prunus sp. & - & $5^{1}$ \\
\hline Humulus lupulus & $17^{1-2}$ & - & Pyrus sp. & - & $5^{1}$ \\
\hline Lonicera xylosteum & $17^{1-2}$ & - & Sanicula europaea & - & $5^{1}$ \\
\hline Taraxacum sect. Ruderalia & $17^{1-2}$ & - & Viburnum opulus & - & $5^{1}$ \\
\hline Veronica chamaedrys & $17^{1-2}$ & - & Fraxinus excelsior & - & $2^{1}$ \\
\hline
\end{tabular}

Cornus mas, Crataegus laevigata, C. monogyna, Euonymus europaeus, E. verrucosus, Hedera helix, Ligustrum vulgare, Quercus cerris, Q. petraea agg., Q. robur, Swida sanguinea, Ulmus 
minor, Viburnum lantana. A common woody plants belonging to forest and clearcut PRP include those woody plants that have probably spread to forest covers from clearcuts, from PA Báb Park or from neighbouring anthropogenic biotopes, for example: Rubus fruticosus agg., Sambucus nigra, Mahonia aquifolium and invasive species Robinia pseudoacacia. Common herbs and grasses mainly include typical forest species: Alliaria petiolata, Brachypodium sylvaticum, Bromus benekenii, Carex pilosa, C. sylvatica, Dentaria bulbifera, Fallopia dumetorum, Ficaria bulbifera, Galeobdolon luteum, Galium odoratum, Glechoma hirsuta, Isopyrum thalictroides, Melica uniflora, Mercurialis perennis, Milium effusum, Poa nemoralis, Polygonatum latifolium, P. multiflorum, Pulmonaria officinalis, Roegneria canina, Viola mirabilis. Also, a ruderal herb Urtica dioica and an invasive herb Impatiens parviflora belong there.

Only clearcuts contain 55 taxa and those are, for example, woody plants such as Lonicera xylosteum, Rosa canina agg, an invasive species called Ailanthus altissima, and of course there are herbs, mainly clearcut and ruderal species such as: Achillea millefolium, Amaranthus retroflexus, Arctium lappa, A. tomentosum, Artemisia vulgaris, Astragalus glycyphyllos, Ballota nigra, Campanula rapunculoides, Capsella bursa-pastoris, Carduus acanthoides, Cirsium arvense, C. canum, C. vulgare, Clematis vitalba, Clinopodium vulgare, Echinochloa crus-galli, Erechtites hieraciifolius, Euphorbia cyparissias, Fragaria moschata, Holosteum umbellatum, Humulus lupulus, Hypericum hirsutum, H. perforatum, Chaerophyllum temulum, Chenopodium hybridum, Inula conyzae, Lamium purpureum, Lathyrus niger, Lavatera thuringiaca, Linaria vulgaris, Persicaria lapathifolia, Sambucus ebulus, Silene latifolia ssp. alba, Solanum dulcamara, Sonchus arvensis, Stellaria media, Taraxacum sect. Ruderalia, Torilis japonica, Tussilago farfara, Verbascum chaixii ssp. austriacum, Vicia angustifolia, V. tetrasperma.

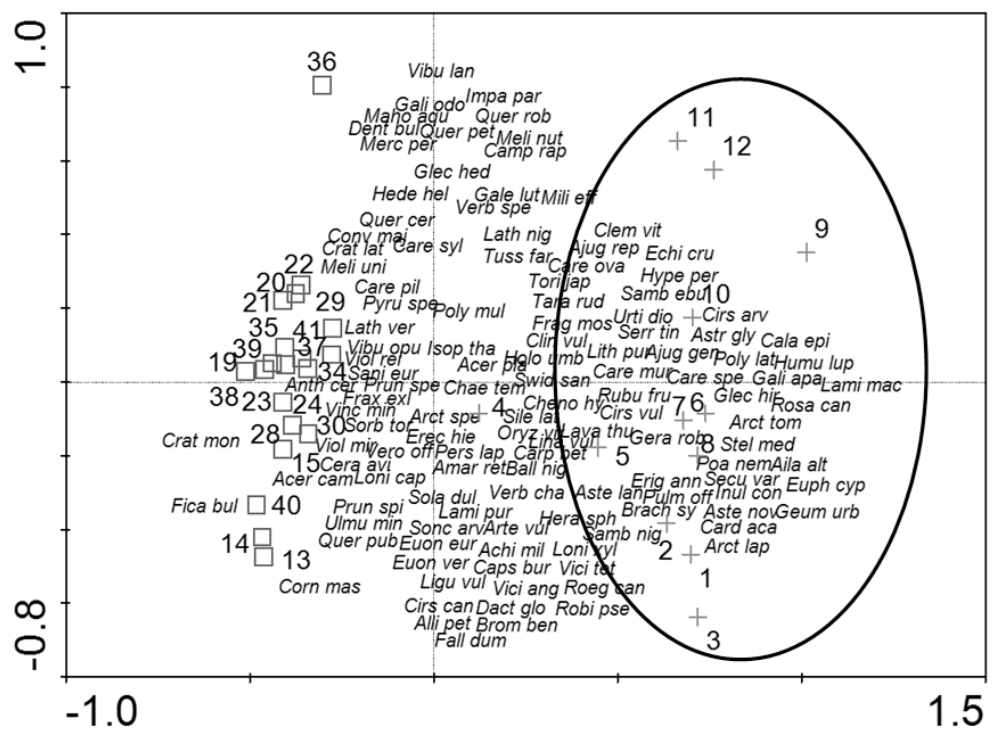

Fig. 2. PCA (Principal component analysis) - summer notes and species structure on two permanent research plots groups. 
Grasses and other similar species occurring on clearcuts, include for example Carex muricata agg., C. ovalis, Melica nutans a Oryzopsis virescens and invasive species include for example Aster lanceolatus, $A$. novi-belgii agg. a Erigeron annuus ssp. annuus. The species that occur on clearcuts only are illustrated in the Fig. 2 (red oval). Only a forest cover environment contained 10 taxa that were woody plants such as Cerasus avium, Fraxinus excelsior, Lonicera caprifolium, Quercus virgiliana, Sorbus torminalis, Viburnum opulus a byliny Anthriscus cerefolium, Convallaria majalis, Sanicula europaea, Veronica officinalis.

The following pictures depict an analysed representation of life forms, life strategies and a representation of indigenous species found on two types of watched habitats. Onwards in the thesis, I work with the summer notes only.

A higher number of taxa (40-60) was found on PRP on clearcuts than in a forest. But the highest number of taxa was found on PRP No. 3 and 9 (60 taxa) and on PRP No. 2 and 11 (58 taxa) (Fig. 3). The reason why the overal number of taxa found on those PRP was so high could be due to the fact that records of taxa included an occurrence of typical forest species and at the same time an occurrence of clearcuts, synanthropic and invasive species. The smallest number of taxa found on clearcuts was found on PRP No. 4 (40 taxa). The truth is that there have been no interventions done on PRP No. 4 since the end of a timber harvesting in 2006 and there is the difference from the other clearcut areas. Out of the all 12 PRP, the previously mentioned area represents the most developed phase of a secondary succession. Dominant plants such as Acer campestre a Carpinus betulus, were documented there and that is what influences a lower occurrence of taxa in a herbal undergrowth. The other PRP on clearcuts represent the areas that are mown twice a year but they have almost the same species composition and cover of an individual species as well.

There was a smaller number of taxa (23-31 species) found on forest PRP than on clearcut PRP. A small difference was caused by a dominance of woody plants and therefore by a following overshadowing of species in an undergrowth. On the other hand, a higher number of taxa on PRP No. 30 (31 taxa), PRP No. 15 and PRP No. 39 (30 taxa) was caused by a close proximity of these forest PRP to neighbouring anthropically affected habitats (a field, clearcuts, PA Báb park).

A Fig. 4 graphically illustrates a cover percentage of a tree, shrub and herb layer. The highest herb layer cover was achieved by PRP on clearcuts. A lower cover associated with the herb layer was found in PRP No. 4 and 5. That result could have been caused by the method of soil management used. Those PRP are not cut and that is why they had the highest cover in a herb and tree layer out of all PRP on clearcuts.

We can divide PRP into two groups: The first group consists of nine PRP (No. 13, 14, $15,19,20,21,22,23,24)$ located in the NNR Bab forest where no forest interventions have been done since 1960s. The fact that there were no interventions is shown in a level of cover of individual layers. The death of old trees and spontaneous recovery happens here, which is evident from higher woody plants cover and lower cover of herbs caused by overshadowing.

The second group consists of 11 PRP (No. 28, 29, 30, 34, 35, 36, 37, 38, 39, 40, 41). Out of these 11 PRP, areas No. 34 and 35 significantly differ from the other areas. They are different because they are influenced by shelterwood felling in a neighbourhood. Shelterwood felling has caused illumination, and therefore high cover of an herb layer and lower cover of a shrub layer. Since forest intrusion in November 2006, a shrub layer has not had a chance to develop 


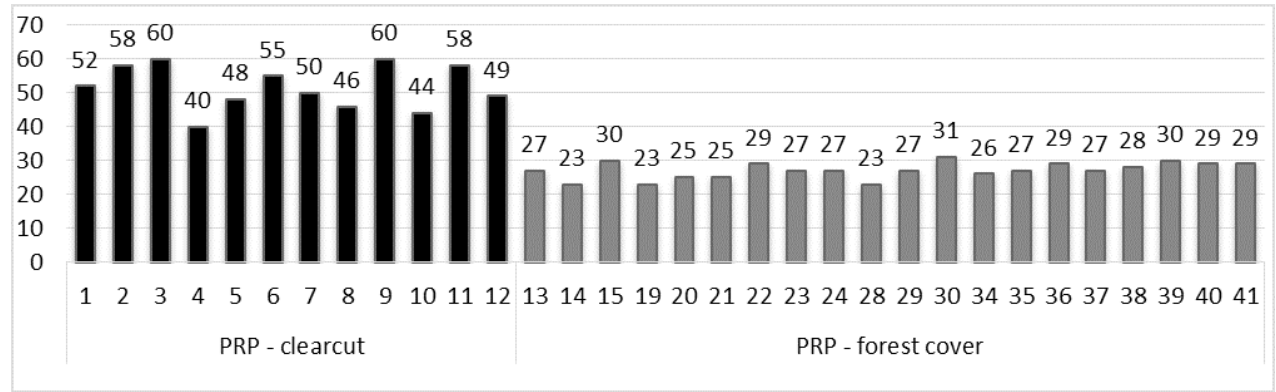

Fig. 3. Number of species on permanent research plots of clearcut areas and forest cover.

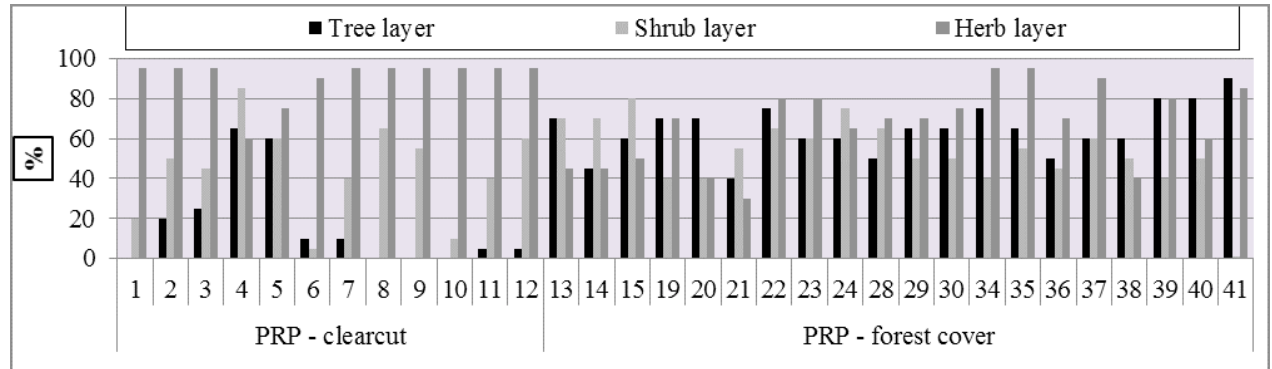

Fig. 4. Cover of tree, shrub and herb layer at 32 permanent research plots in the Báb forest.

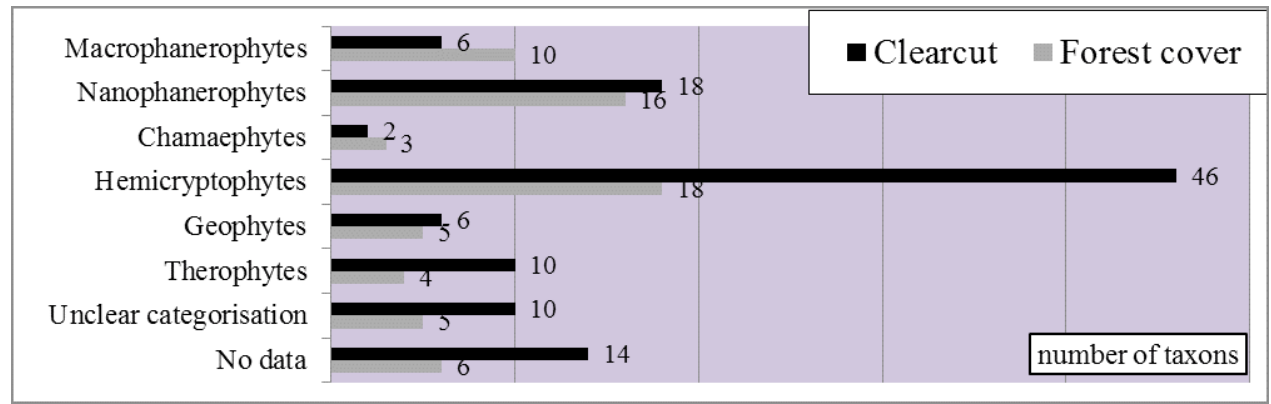

Fig. 5. Representation of plant life forms on permanent research plots of clearcut and forest vegetation.

fully. PRP No. 41 significantly differs from the other areas because it was found that cover of a shrub layer was $1 \%$. Foresters have cleaned that section of the forest where the area of woody plants and fallen trees were located.

A representation of taxon life forms occurring on PRP is depicted in the Fig. 5. The biggest difference is in the number of hemicrytophytes: clearcuts - 46 species, forest covers - 18 species. Hemicrytophytes which are typical for disturbed areas (Arctium lappa, A. tomentosum, Aster lanceolatus, Ballota nigra, Hypericum hirsutum, Sambucus ebulus, Verbascum austriacum) where found on clearcuts only. 
There are also big age differences between annual and biennial plants: clearcuts - 10 species, forest cover -4 species. Therophytes located in both PRP groups are Galium aparine, Geranium robertianum, Impatiens parviflora. On the clearcut areas, there were aedes species such as: Carduus acanthoides, Echinochloa crus-galli, Erechtites hieraciifolius, Erigeron annuus ssp. annuus, Torilis japonica, Vicia angustifolia, V. tetrasperma.

A representation of other life forms such as chamaephytes, geophytes is basically the same on clearcuts and forest covers. Because of a clearcut harvesting, the clearcuts contain a lower number of macrophanerophytes and a higher number of nanophanerophytes than forest covers do.

Also a direct ordination (RDA) of life forms confirms the previously mentioned results (Fig. 6). All the factors together can explain $48 \%$ of variability in the case of species data. In the case of $95 \%$ reliability, there were some significant changes found. These significant changes in reliability were documented in life forms such as: hemicrytophytes, geophytes, nanophanerophytes, macrophanerophytes. The value of $\mathrm{p}$ is less than 0.01 . Other life forms such as therophytes and chamaephytes did not have such significant influence on the species data variability.

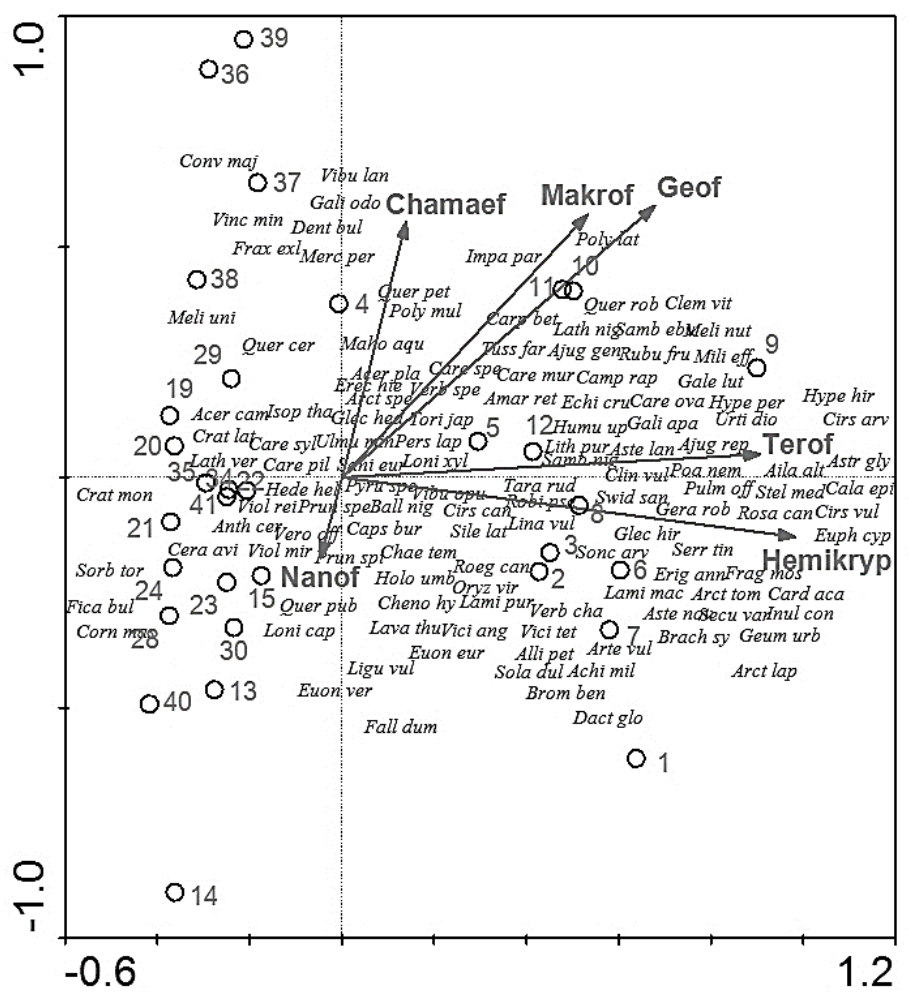

Fig. 6. RDA (Regression-Discontinuity Analysis) ordination of life forms in the Báb forest. 
A Fig. 7 depicts a representation of taxa life strategies in the Báb forest. The biggest differences between forests and clearcuts are shown in a representation of C-strategies, and in the case of clearcuts there were found new competitors such as Arctium lappa, Aster lanceolatus, Cirsium arvense, Clematis vitalba, Hypericum hirsutum, $H$. perforatum, Rosa canina agg., Sambucus ebulus, Torilis japonica. They represent clearcut, synanthropic and invasive taxa. Also, bigger differences between forests and clearcuts are shown in a representation of CSR-strategies, and new taxa found on clearcuts were: Ajuga genevensis, Fragaria moschata, Lathyrus niger, Linaria vulgaris, Melica nutans, Taraxacum sect. Ruderalia, Tussilago farfara.

Other differences were found in a representation of CR-strategies and an increase of species such as Amaranthus retroflexus, Carduus acanthoides, Cirsium vulgare, Echinochloa crusgalli, Chaerophyllum temulum, Chenopodium hybridum, Persicaria lapathifolia, Stellaria media happens of clearcut PRP. A significant difference was also documented in the R-strategy, the representatives of which occur on PRP located on clearcuts only. They include: Capsella bursa-pastoris, Lamium purpureum, Vicia angustifolia, V. tetrasperma. In the case of other categories, there were observed no significant differences between forest and clearcut PRP.

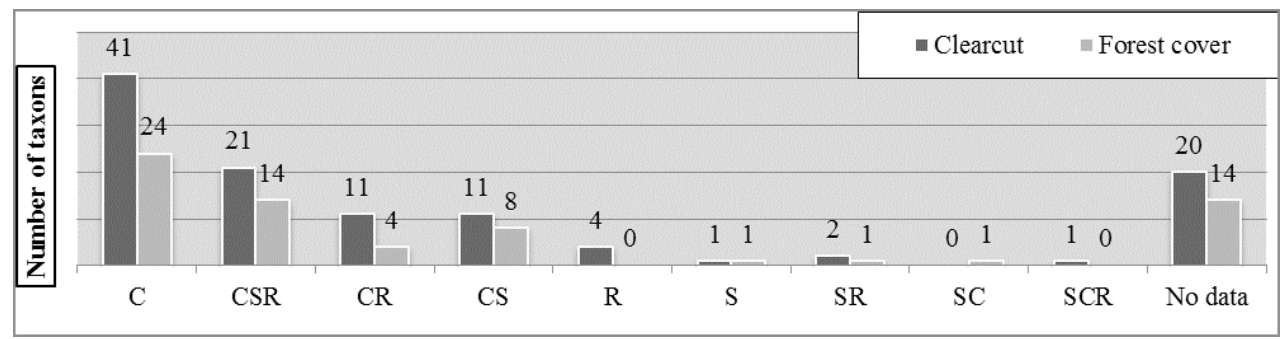

Fig. 7. Representation of plant life strategies on permanent research plots of clearcut areas and forest vegetation.

The given results are confirmed by a direct ordination (RDA) of representation of taxon life strategies in Báb forest (Fig. 8). Individual strategies explain together $56 \%$ variability of species data. The most significant factors (the value of $p$ is less than 0.01 ) influencing a variability of phytocenologic data are CSR, CR, C, SR, CS strategies. A very significant influence is represented by R, SC, S strategies as well.

A representation of taxon synanthropy on clearcut and forest cover PRP is illustrated in Fig. 9. The highest number of taxa was achieved by indigenous species (native plants growing on natural habitats and original communities only) and by apophytes (domestic taxa growing in natural communities but also on modified or synanthropic habitats). These taxa were found in clearcut areas and in forest covers at the same time.

Archaeophytes (plants have been introduced in a contemporary area in Slovakia since $15^{\text {th }}$ century) were occurring only on PRP on clearcuts and they included these species: Arctium lappa, A. tomentosum, Ballota nigra, Capsella bursa-pastoris, Carduus acanthoides, Chenopodium hybridum, Lamium purpureum, Silene latifolia ssp. alba, Sonchus arvensis, Vicia angustifolia, V. tetrasperma. And neophyte Mahonia aquifolium (a herb introduced into a contemporary area 


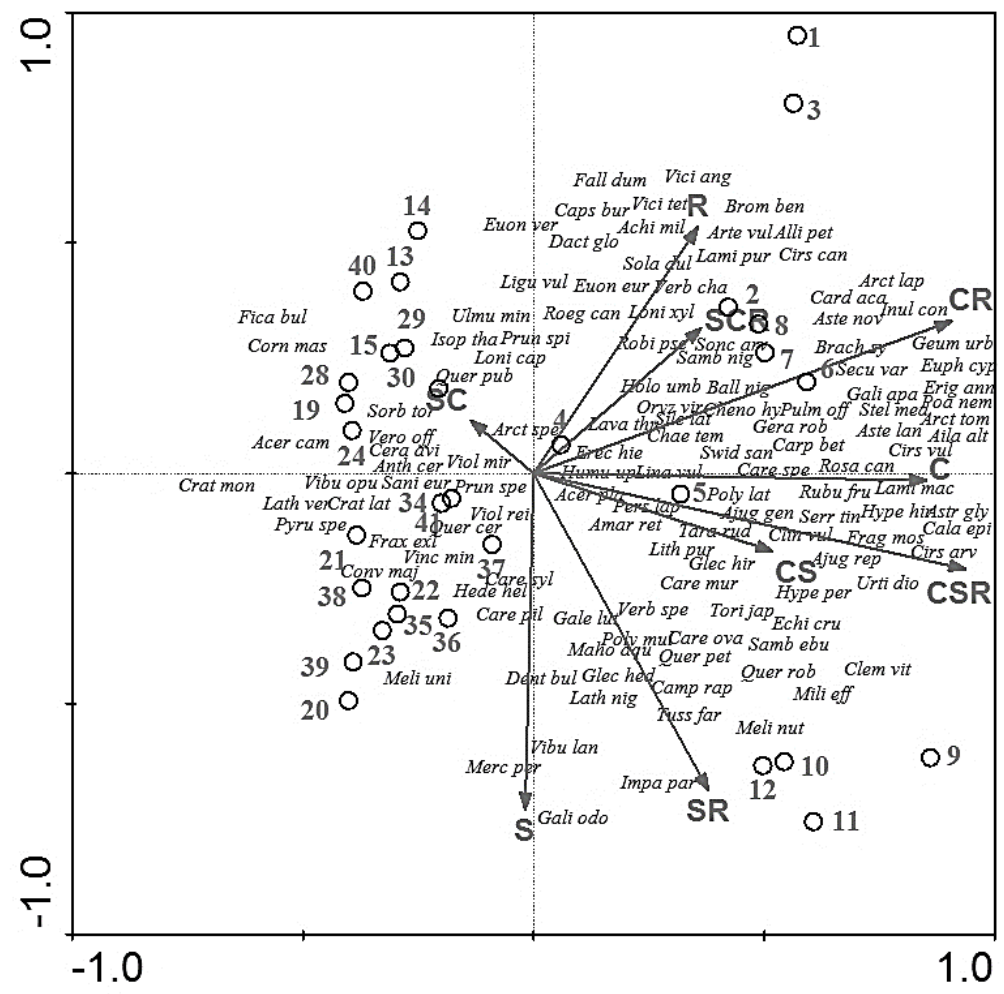

Fig. 8. RDA ordination of life strategies in the Báb forest.

in the $15^{\text {th }}$ century) occurred on clearcuts and forest covers. Neophytes located on clearcuts included Erechtites hieraciifolium, Torilis japonica and neophytes with an occurrence in forest covers only included Anthriscus cerefolium, Lonicera caprifolium. Echinochloa crus-galli belonged to invasive archaeophytes located on clearcuts only. On PRP on clearcuts and forest covers, there were found invasive neophytes such as Impatiens parvifloraa Robinia pseudoacacia and invasive neophytes including Ailanthus altissima, Amaranthus retroflexus, Aster lanceolatus, A. novi-belgii agg., Erigeron annuus ssp. Annuus were found on clearcuts only.

Fig. 10 depicts synanthropy. In the case of this factor, there was found a significant change in $95 \%$ of reliability (the value of $p$ is less than 0.01 ) and a given factor can explain $23 \%$ of variability. The most invaded clearcut areas were PRP No. 1, 2, 3. They were placed in the closest proximity to a field and that is why such a great spreading of archaeophytes, neophytes and invasive species has happend. There was also found a great invasion of PRP No. 5, 6 (high cover especially in Ailanthus altissima a Robinia pseudoacacia) and PRP No. 9 (especially Ailanthus altissima and invasive herbs such as Aster lanceolatus, A. novi-belgii agg., Erigeron annuus ssp. annuus). 


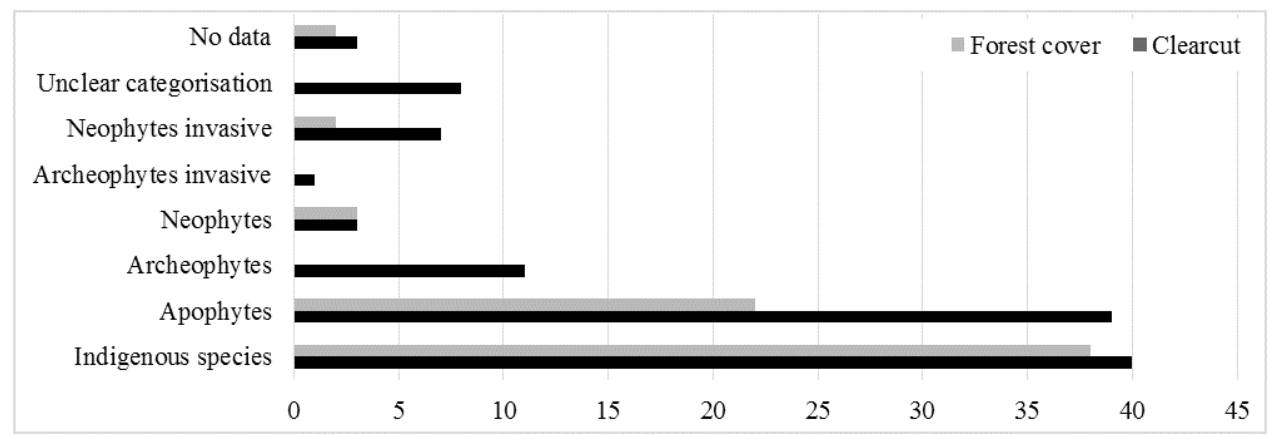

Fig. 9. Number of taxa in groups of plant taxa found on the clearcut areas and in the forest.

The least invaded non-indigenous species were PRP on clearcuts No. 4, 8, 10, 11, 12. PRP No. 4 shows the biggest overgrowth by indigenous forest woody plants and that is the reason why light-demanding indigenous plants could not spread. The features such as low cover and a low number of non-indigenous species represent characteristic features of the rest of PRP

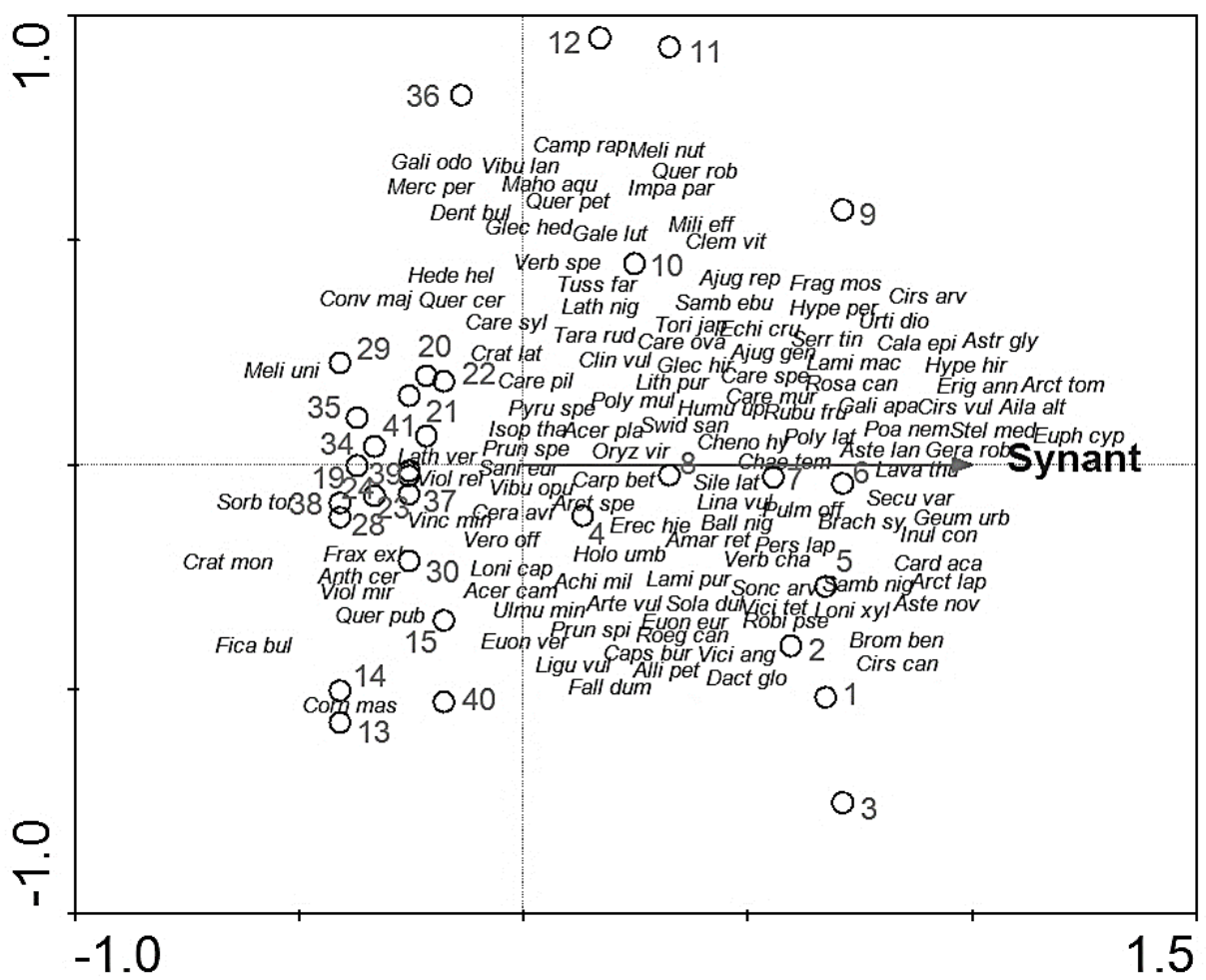

Fig. 10. Synanthropisation of permanent research plots. 
(No. 8, 10, 11, 12). The areas and the edge of a forest are located the furthest from each other and that is why there is a possibility to see a distance as a markant influence for spreading of non-indigenous taxa. Within the area of forest PRP, the most invaded areas were areas No. 22, No. 15 (Anthriscus cerefolium, Impatiens parviflora) and No. 40, No. 36 (especially Impatiens parviflora, Mahonia aquifolium). There was not any evidence found which would confirm an influence of a distance on spreading of non-indigenous taxa. There are no nonindigenus species occurring in forest PRP No. 13, 14, 24, 28, 29.

\section{Discussion}

This research confirmed the presence of those typical plants belonging to oak-hornbeam forests. They are mentioned by Kubíček, Brechtl (1970) and those are for example: Acer campestre, Acer platanoides, Carpinus betulus, Cerasus avium, Cornus mas, Crataegus laevigata, Euonymus verrucosus, Hedera helix, Ligustrum vulgare, Quercus cerris, Quercus petreae agg., Quercus robur, Robinia pseudoacacia, Rosa canina agg., Sorbus torminalis, Ulmus minor. There were also found new woody plants with high cover (the year 2013): Ailanthus altissima, Crataegus monogyna, Euonymus europaeus, Fraxinus excelsior, Lonicera caprifolium, L. xylosteum, Mahonia aquifolium, Rubus fruticosus agg., Quercus virgiliana, Sambucus nigra, Swida sanguinea.

Common herbs and grasses include: Ajuga reptans, Anemone ranunculoides, Brachypodium sylvaticum, Carex muricata agg., Carex pilosa, Convallaria majalis, Cruciata laevipes, Dentaria bulbifera, Ficaria bulbifera, Galeobdolon luteum, G. odoratum, Geranium robertianum, Geum urbanum, Glechoma hirsuta, Hedera helix, Heracleum sphondylium, Chaerophyllum temulum, Isopyrum thalictroides, Lamium maculatum, Lathyrus niger, L. vernus, Lithospermum purpurocaeruleum, Melica nutans, M. uniflora, Mercurialis perennis, Milium effusum, Poa nemoralis, Polygonatum latifolium, P. multiflorum, Pulmonaria officinalis, Roegneria canina, Sanicula europaea, Torilis japonica, Viola mirabilis, V. odorata, V. reichenbachiana. There were documented more common species in 2013 with very vhigh cover: Alliaria officinalis, Dactylis glomerata, Euphorbia cyparissias, Galium aparine, Hypericum perforatum, Urtica dioica. They were found on clearcuts mainly and in high amount of cover. There were documented new high cover herbs that were found on clearcut PRP such as: Ajuga genevensis, Arctium lappa, A. tomentosum, Aster lanceolatus, Astragalus glycyphyllos, Ballota nigra, Calamagrostis epigejos, Carduus acanthoides, Cirsium arvense, C. vulgare, Erigeron annuus ssp. annuus, Hypericum hirsutum, Impatiens parviflora, Inula conyzae, Sambucus ebulus, Serratula tinctoria, Stellaria media.

Fragments of forests in a deforested country being intensively exploited by agriculturers are exposed to impacts of human activities (Eliáś, 2010b). Due to this intervention, the expansion of photophilous ruderal, synanthropic and invasive species into the Báb forest clearcuts from the surrounding anthropogenic biotopes has increased even more. Moreover, photophilous clearcut species and the species of forest open parts and forest edges began to settle in the clearcuts.

In the case of two watched types of habitats, the inequality in a species composition (forest-clearcut) is caused by various levels of overshadowing. On clearcuts, it is possible to 
notice spreading of different species and it is possible because of a presence of kept herbs and regular mowing. In forest covers because of lightening and because of older woody plants death, light-demanding species are inserting into forest covers. The species composition can also change under the influence of human beings, for example when species such as Impatiens parviflora were introduced there or because of different taxon spreading methods, for example by birds (Mahonia aquifolium), by a clonal growth (Vinca minor) or by firing of seeds into greater distances (Impatiens parviflora).

The species composition can change based on distance between PRP and anthropogenic biotopes - cultivated fields, PA Báb Park, residential area Alexandrov dvor or between clearcuts with their synanthropic and clearcut species. A closeness of those anthropically disturbed areas is caused by fast supply of diaspors because of air, animals or humns.

A higher number of taxa on clearcuts is caused by a combination of light-demanding and shade tolerant plants. These plants have remained from forest cover. Then, it is a penetration of synanthropic, clearcut and invasive species into new and free ecologic niche. The penetration happens from adjacent agricultural lands, rural paths and a residential area, Alexandrov dvor. The majority of these species on clearcuts belongs to life forms, hemicrytophytes and therophytes. The combinations of life strategies with R-strategy such as CSR-strategy, CR and then R- strategy dominate on clearcut PRP. At the same time, C-strategy has significantly increased its occurrence on clearcut PRP and it was formed by woody plants of forest edges as Rosa canina agg., Sambucus nigra, then synantrophic Arctium lappa, A. tomentosum, Cirsium arvense, Sambucus ebulus, Serratula tinctoria and invasive herbs Aster lanceolatus, A. novibelgii agg. in high cover. We claim that a representation of life forms and life strategies has considerably changed because of the creation of clearcuts and because of the establishment of synanthropic, clearcut and invasive taxons.

Specific features of forest communities include a bigger overshadowing of covers and also an interspecific competition. Plus, those features are the reason why non-indigenous and synanthropic species have not spread more. However, the invasive species such as Impatiens parviflora a Robinia pseudoacacia has already spread in an overshadowed forest cover. For the future, we anticipate a retreat of light-demanding species caused by overgrowing of clearcuts or after a death of older woody plants and they will move to more illuminated places.

An occurrence of non-indigenous species in Babsky forest is a result of proximity between anthropogenically disrupted biotopes with their non-indigenous either synanthropic, invasive, or cultivated species. Clearcut timber harvesting in November 2006 has increased an occurrence of those particular species in Babsky les. In November 2006, there arised four new clearcuts, indigenous covers were removed and therefore a space opening for diaspors and a change of light conditions happend.

A great attention should be paid to invasive species of woody plants such as Ailanthus altissima and Robinia pseudoacacia and to species that spread very quickly. Woody plants Ailanthus altissima a Robinia pseudoacacia growing in Babsky forest are implemented in the works of Halada et al. (2010) and Eliáš (2010a). In brief period of time the spreading of these invasive woody plants will be happening, and mainly it will take place on clearcuts of Báb forest. Moreover, spreading of diaspors from adjacent anthropically disrupted area will be happening. On the other hand, in the future, their relocation may happen or they may disap- 
pear thanks to changing light and competitive conditions (growth of seedlings Quercus robur a Q. petraea agg. and therefore clearcut overshadowing and displacing, on the other hand, an open illuminated space after a spontaneous recovery in a forest cover).

Archaeophytes such as - Arctium lappa, Arctium tomentosum, Ballota nigra, Carduus acanthoides, Lamium purpureum belong to non-indigenous species with high cover. For the given herbs, the characteristic occurrence is in the areas that were disrupted by people and they intensively spread on clearcut PRP. These clearcuts PRP are adjacent to antropically modified habitats. The given species has used a new ecologic niche and more specifically a change of light and competing conditions. In the case of the woody plant Mahonia aquifolium, its spreading into futher parts of Báb forest has occured. The spreading probably began in PA Báb Park and probably PA Báb Park is the place from which Eliáš (2010a) described it. The work Halada et al. (2010) also confirms the occurrence of some taxons; it is, for example, Aster lanceolatus, Impatiens parviflora, Lamium purpureum, Erigeron annuus ssp. annuus.

An invasive herb called Impatiens parviflora showed higher cover on clearcuts than on forest PRP. Impatiens parviflora was introduced into the park in 1980s and in the mid-1980s, the herb was found in a forest cover around the field laboratory. With the help of people, the herbs has spread into distant parts of a forest, Báb forest included (Eliáš, 2010b). This herb is capable of growing in shadow, warmth, and humidity, and nitrogen environment is no problem for it either. Báb forest provides all of these mentioned conditions either in forest covers or in clearcuts. I suppose that spreading of light-demanding indigenous species on clearcuts will continue under the influence of mowing. However, because of growth, overshadowing and pushing seedlings such as Quercus robur a Quercus petraea agg out, these species will retire and die out, in the future.

Specific features of forest communities include overshadowing and interspecific competition and that is why it may be very difficult for non-indigenous species to spread. In the case of light changes, under the influence of natural dying of older woody plants, the spreading of light-demanding non-indigenous species either from clearcuts or from adjacent anthropogenic biotopes into various forest covers may happen. Non-indigenous species that can tolerate higher or lower overshadowing, such as Impatiens parviflora, with a large occurrence, may be spread in forest covers as well.

\section{Conclusion}

In the submitted paper, we have summarised the results of a research that was realised in the locality of the Báb forest. The Báb forest is a lowland oak-hornbeam forest that represents the rest of indigenous forest complexes situated originally in the loess upland area. Therefore, it represents a climax stage of forest succession on loess. The target is to evaluate the biodiversity of plant species of two permanent area groups - PRP of clearcut areas and of forest cover.

In the area of Báb forest, I was able to document 134 higher plants on 32 PRP during 2013. Out of the overal number of 134 higher plants, there were found 31 plants and 98 herbs. One hundred and twenty-three taxa were documented in PRP areas situated on clearcuts, while only 75 taxa were found in PRP areas located in forest covers. On PRP of clearcuts, there is the highest cover of herb layer, while on the other hand, in the forest cover, there is a 
higher cover of shrub and tree layer. The highest differences in life forms between two groups of PRP (clearcuts/forest) were detected by hemicryptophytes and therophytes. On all 32 areas, the biggest number of species belongs to indigenous species and apophytes. The biggest differences are shown in a representation of C-strategies.

Four new clearcut areas, six open stands arose after realisation of clear and shelterwood fellings in November 2006 and subsequently a change of plant species composition occurred. The logging created suitable conditions for penetration of non-indigenous species from the surrounding (mainly anthropogenic) habitats. That is why there are largely synanthropic and non-indigenous taxa represented on permanent clearcut areas that are spreading further into the forest stand as well as distant areas of the Báb forest.

\section{References}

Dostál, J. (1991). Velký klúč na určovanie vyšších rastlín I. Bratislava: SPN.

Dostál, J. (1992). Velký klúč na určovanie vyšších rastlín II. Bratislava: SPN.

Eliáš, P. (2010a). Zmeny biodiverzity v Bábskom lese a blízkom okolí (Nitrianska pahorkatina, Juhozápadné Slovensko). In M. Eliašová (Ed.), Starostlivost’o biodiverzitu vo vidieckej krajine (pp. 151-158). Nitra: SPU.

Eliáš, P. (2010b). Fenotypové plastické odpovede netýkavky malokvetej (Impatiens parviflora) nazmeny prostredia po tažbe stromov v lese. Rosalia, 21, 33-46.

Frank, D. \& Klotz S. (1988): Biologisch-ökologische daten zur flora der DDR. Wissenschaftliche Beiträge der Martin Luther Universität in Halle-Wittemberg.

Halada, L. (1996). Hodnotenie prirodzenosti/synantropizácie vegetácie pre krajinno-ekologické účely. Práca $\mathrm{k}$ ašpirantskému minimu, Ústav krajinnej ekológie SAV, Nitra.

Halada, L., David, S. \& Eliáš P. (2010). Druhové zloženie bylinného poschodia výskumnej plochy Báb pri Nitre. Rosalia, 21, 19-32.

Hennekens, S.M. \& Schaminee J.H.J. (2001). TURBOVEG: Comprehensive data base management system for vegetation data. J. Veg. Sci., 12, 589-591. DOI: 10.2307/3237010.

Kubíček, F. \& Brechtl J. (1970). Charakteristika skupín lesných typov výskumnej plochy v Bábe pri Nitre. Biológia, 25(1), 27-38.

Lepš, J. \& Šmilauer P. (2000). Mnohorozměrná analýza ekologických dat. České Budějovice: Biologická fakulta Jihočeské univerzity.

Marhold, K. \& Hindák F. (Eds.) (1998). Zoznam nižších a vyšších rastlín Slovenska. Bratislava: VEDA.

Medvecká, J., Kliment, J., Májeková, J., Halada, L., Zaliberová, M., Gojdičová, E., Feráková, V. \& Jarolímek I. (2012). Inventory of the alien flora of Slovakia. Preslia, 84, 257-309.

Moravec, J. (1994). Fytocenologie. Praha: Academia.

Tichý, L. (2002). JUICE, software for vegetation classification. J. Veg. Sci., 13, 451-453. DOI: 10.1111/j.1654-1103.2002. tb02069.x.

Westhoff, W. \& Van den Maarel E. (1978). The Braun-Blanquet approach. In R.H. Whittaker (Ed.), Classification of plant communities (pp. 287-399). The Hague: Dr. W. Junk. 